Tropical Journal of Pharmaceutical Research November 2016; 15 (11): 2337-2343

ISSN: $1596-5996$ (print); 1596-9827 (electronic)

(C) Pharmacotherapy Group, Faculty of Pharmacy, University of Benin, Benin City, 300001 Nigeria.

All rights reserved.

Available online at http://www.tjpr.org

Original Research Article

http://dx.doi.org/10.4314/tjpr.v15i11.6

\title{
Inhibitory activity of benzo[h]quinoline and benzo[h]chromene in human glioblastoma cells
}

\author{
Mogedda E Haiba ${ }^{1 *}$, Ebtehal S Al-Abdullah ${ }^{2}$, Hazem A Ghabbour ${ }^{2,3}$, Sayed M \\ Riyadh $^{4,5}$, Reham M Abdel-Kader ${ }^{6}$ \\ ${ }^{1}$ Department of Therapeutical Chemistry, Pharmaceutical and Drug Industries Division, National Research Center, Tahrir \\ Street, Dokki, Cairo 12622, Egypt, ${ }^{2}$ Department of Pharmaceutical Chemistry, College of Pharmacy, King Saud University, \\ Riyadh 11451, Saudi Arabia, ${ }^{3}$ Department of Medicinal Chemistry, Faculty of Pharmacy, University of Mansoura, Mansoura \\ 35516, ${ }^{4}$ Department of Chemistry, Faculty of Science, Cairo University, Giza 12613, Egypt, ${ }^{5}$ Department of Chemistry, Faculty \\ of Science, Taibah University, Almadinah Almunawarah 30002, Saudi Arabia, ${ }^{6}$ Department of Pharmacology \& Toxicology, \\ Faculty of Pharmacy and Biotechnology, German University in Cairo, Egypt
}

*For correspondence: Email: mogedda.haiba@yahoo.com

Received: 19 April 2016

Revised accepted: 10 October 2016

\begin{abstract}
Purpose: To carry out a neat synthesis of 2-amino-5,6-dihydro-8-methoxy-4-phenylbenzo[h]quinoline-3carbonitrile (compound 2) and 2-amino-5,6-dihydro-8-methoxy-4-phenyl-4H-benzo[h]chromene-3carbonitrile (compound 3) and evaluate their cytotoxic activity in human glioblastoma cells.

Methods: Benzo[h]quinoline and benzo[h]chromene were synthesized by treating 6-methoxy-1tetralone with benzylidenemalononitrile under microwave irradiation. The structures of compounds 2 and 3 were confirmed by elemental, spectral, and x-ray crystallographic analyses. The cytotoxic activity of compounds 2 and 3 was evaluated using WST-1 assay in U373 human glioblastoma cell line.

Results: The molecular structures of compounds 2 and 3 were demonstrated unambiguously from single crystal $x$-ray measurements and they crystallized in triclinic form, P-1, for both compounds. Invitro cytotoxic activity data for compound 2 in human glioblastoma cell line (U373) indicate that no significant cytotoxicity was observed. On the other hand, compound 3 showed highly significant cytotoxic effects on U373 cells at concentrations starting from $0.1 \mu \mathrm{g} / \mathrm{mL}$.

Conclusion: Compound 3 produces a decrease in cell viability with approximately $80 \%$ cell death while compound 2 did not indicate significant cytotoxic activity. This suggests that the chromene moiety of compound 3 may be responsible for its high cytotoxicity.
\end{abstract}

Keywords: Hydronaphthaline, Benzo[h]quinolone, Benzo[h]chromene, X-ray crystallography, U373 human glioblastoma, Cytotoxicity, Chromene moiety

Tropical Journal of Pharmaceutical Research is indexed by Science Citation Index (SciSearch), Scopus, International Pharmaceutical Abstract, Chemical Abstracts, Embase, Index Copernicus, EBSCO, African Index Medicus, JournalSeek, Journal Citation Reports/Science Edition, Directory of Open Access Journals (DOAJ), African Journal Online, Bioline International, Open-J-Gate and Pharmacy Abstracts

\section{INTRODUCTION}

Literature survey has demonstrated the diversity of pharmacological applications of fused chromenes such as, anticancer [1,2], antibacterial [3], anti-inflammatory [4], antioxidants [5,6] and antiprotozoal [7] activities. Also, fused quinoline derivatives produce wide pharmacological activities such as antibacterial
$[8,9]$, antifungal [10], antimalarial [11], antiplasmodium [12] and anticancer [13,14] effects. Moreover, they have been reported to act as vesicular glutamate transporters [15] and HIVIntegrase inhibitors [16]. The combination of different ring systems in one compound is one of the major tools implemented in this study to produce more biologically active products in the field of drug development, aiming to obtain more 
active and less toxic products. Based on the above knowledge and in continuation of our previous work [17-19], the present study provides an evidence for the high efficient biological activity of the synthesized benzo[h]quinoline and benzo[h]chromene derivatives as anticancer compounds.

\section{EXPERIMENTAL}

\section{Materials and instruments}

Melting points were recorded on a Barnstead 9001 Electrothermal melting point apparatus and are uncorrected. IR spectra were recorded on a Perkin Elmer FT-IR Spectrum BX Spectrometer at $\mathrm{cm}^{-1}$ scale using $\mathrm{KBr}$ discs. ${ }^{1} \mathrm{H}-\mathrm{NMR}$ and ${ }^{13} \mathrm{C}$ NMR were recorded on a JEOL $500 \mathrm{MHz}$ Spectrometer, (Japan) and chemical shift values were expressed in $\delta$ values (ppm) relative to tetramethylsilane (TMS) as an internal standard. Coupling constants are given in $\mathrm{Hz}$. The mass spectra were recorded on GCMC-QP 1000 EX Shimadzo Gas Chromatography MS spectrometer, (Japan) E.I. 70 ev. Elemental analysis $(\mathrm{C}, \mathrm{H}, \mathrm{N})$ were carried out at the Micro analytical Center, Faculty of Science, Cairo University, Egypt, and were in full agreement with the proposed structures within $\pm 0.1-0.2 \%$ of the theoretical values. All reagents were of analytical grade. The reactions was followed up by analytical thin layer chromatography (TLC) on pre-coated $(0.75 \mathrm{~mm}$ ) silica gel GF254 plates (E. Merck, Germany) and the products were visualized by UV light at $254 \mathrm{~nm}$.

\section{Synthesis of 2-amino-5,6-dihydro-8-methoxy- 4-phenyl-benzo[h]quinoline-3-carbonitrile (2)}

In a $5 \mathrm{~mL}$ glass tube, to a mixture of 6-methoxy1-tetralone (1) $(0.176 \mathrm{~g}, 0.001 \mathrm{~mol}), 2-$ benzylidenemalononitrile $(0.154 \mathrm{~g}, 0.001 \mathrm{~mol})$ in ethanol $(3 \mathrm{~mL})$, ammonium acetate $(0.154 \mathrm{~g}$, $0.002 \mathrm{~mol})$, few drops of piperidine were added. The reaction tube was placed inside the cavity of the microwave synthesis system the tube was irradiated in the microwave oven with a power of $400 \mathrm{~W}$, at a temperature of $130{ }^{\circ} \mathrm{C}$, for $15 \mathrm{~min}$. After completion of the reaction (monitored by TLC) and cooling, the solid formed was filtered off, washed with dilute cold ethyl alcohol and recrystallized from ethyl alcohol to give compound 2.

Synthesis of 2-amino-5,6-dihydro-8-methoxy4-phenyl-4H-benzo[h]chromene-3-carbonitrile (3)

In a $5 \mathrm{~mL}$ glass tube, a mixture of 6-methoxy-1tetralone (1) $(0.176 \mathrm{~g}, \quad 0.001 \mathrm{~mol}), \quad 2-$ benzylidenemalononitrile $(0.154 \mathrm{~g}, 0.001 \mathrm{~mol})$ in ethanol $(3 \mathrm{~mL})$, few drops of piperidine were added. The reaction tube was placed inside the cavity of the microwave synthesis system, the tube was irradiated in the microwave oven with a power of $400 \mathrm{~W}$, at a temperature of $130^{\circ} \mathrm{C}$, for 15 min. After completion of the reaction (monitored by TLC) and cooling, the solid formed was filtered off, washed with dilute cold ethyl alcohol and recrystallized from ethyl alcohol to yield compound $\mathbf{3}$.

\section{X-ray crystallographic analysis}

Compounds 2 and 3 were obtained as single crystals by slow evaporation from ethanol solution of the pure compound at room temperature. Data were collected on a Bruker APEX-II D8 Venture diffractometer, worked with graphite monochromatic Mo Ka radiation at 100 (2) K. Cell refinement and data reduction were carried out by Bruker SAINT. SHELXS-97 [20, 21] was used to solve the structures. The final refinement was carried out by full-matrix leastsquares techniques with anisotropic thermal data for nonhydrogen atoms on F. CCDC 140449 and 1404416 contains the supplementary crystallographic data for these compounds and can be obtained free of charge from the Cambridge Crystallographic Data Centre via www.ccdc.cam.ac.uk/data_request/cif.

\section{Cytotoxicity evaluation}

U373 human glioblastoma cell line was used to evaluate the cytotoxicity of the compounds. U373 cells were maintained in DMEM medium containing $10 \%$ fetal bovine serum and $1 \%$ penicillin/streptomycin. Cells were seeded in 96 well plates at a density of 5000 cells/well in a final volume of $100 \mu \mathrm{L} /$ well overnight at $37{ }^{\circ} \mathrm{C}$ and $5 \% \mathrm{CO}_{2}$. Compounds $\mathbf{2}$ and $\mathbf{3}$ were dissolved in DMSO and 5 different concentrations $(0.1,1,10,100$ and $200 \mu \mathrm{g} / \mathrm{mL})$ were prepared from each compound.

Drugs were added to the cells and the plates were incubated for an additional 48 hours at 37 ${ }^{\circ} \mathrm{C}$ and $5 \% \mathrm{CO}_{2}$. Control cells were incubated with DMSO only. Cell viability was assayed using WST-1 assay (Clontech) according to the manufacturer's protocol. Briefly, $10 \mu \mathrm{L}$ of Premixed WST-1 Cell Proliferation Reagent was added to each well after drug incubation for $48 \mathrm{~h}$ and absorbance was measured $4 \mathrm{~h}$ later at 450 $\mathrm{nm}$ using Perkin Elmer Victor 1530 plate reader. Each experiment was performed in duplicates, and experiments were repeated for each concentration 3 or 4 times. 


\section{Statistical analysis}

Data were analyzed using Prism 5.0 software (GraphPad Software, LaJolla, CA, USA). Statistical significance was assessed by one-way ANOVA test. Data are expressed as mean \pm SEM. $P<0.05$ was considered statistically significant.

\section{RESULTS}

Subjecting a mixture of 6-methoxy-1-tetralone (1), benzylidenemalononitrile, ammonium acetate (in molar ratio 1:1:2, respectively) in ethanol, and drops of piperidine as a catalyst, to microwave irradiation afforded 2-amino-5,6-dihydro-8methoxy-4-phenyl-benzo[h] quinoline-3carbonitrile (2) as the isolated product (Scheme 1).

On the other hand, subjecting a similar amount of the mixture 6-methoxy-1-tetralone (1), benzylidenemalononitrile in ethanol and drops of piperidine to microwave irradiation under the same reaction conditions, however in the absence of ammonium acetate, furnished the respective 2-amino-5,6-dihydro-8-methoxy-4phenyl-4H-benzo[h] chromene-3-carbonitrile (3) (cf. Scheme 1).

The structures of compounds $\mathbf{2}$ and $\mathbf{3}$ were confirmed by their elemental, spectral, (IR, ${ }^{1} \mathrm{H}$ NMR, ${ }^{13} \mathrm{C}$ NMR and MS) and x-ray crystallographic analyses.

\section{2-Amino-5,6-dihydro-8-methoxy-4-phenyl- benzo[h]quinoline-3-carbonitrile (2)}

Yield $80 \%$; m.p.: 222-224 ${ }^{\circ} \mathrm{C}$; IR $\left(U_{\max } / \mathrm{cm}^{-1}\right)$ : 3475, $3379\left(\mathrm{NH}_{2}\right), 2208(\mathrm{CN}), 1625(\mathrm{C}=\mathrm{N}) ;{ }^{1} \mathrm{H}-$ $\operatorname{NMR}\left(\mathrm{CDCl}_{3}\right): \delta, 2.6\left(\mathrm{~m}, 2 \mathrm{H}, \mathrm{CH}_{2}\right), 2.7(\mathrm{~m}, 2 \mathrm{H}$, $\left.\mathrm{CH}_{2}\right), 3.8\left(\mathrm{~s}, 3 \mathrm{H}, \mathrm{OCH}_{3}\right), 5.1\left(\mathrm{~s}, 2 \mathrm{H}, \mathrm{NH}_{2}\right), 6.7$ (s, $1 \mathrm{H}, \mathrm{Ar}, \mathrm{CH}-7), 6.8(\mathrm{~d}, J=8.4 \mathrm{~Hz}, 1 \mathrm{H}, \mathrm{Ar}-\mathrm{CH}-$ 9), $7.3\left(\mathrm{~m}, 2 \mathrm{H}, \mathrm{Ar}-\mathrm{CH}-2^{\prime}, 6^{\circ}\right), 7.4-7.5(\mathrm{~m}, 3 \mathrm{H}, \mathrm{Ar}-$ $\left.\mathrm{CH}-3^{\circ}, 4^{\circ}, 5^{\circ}\right), 8.2(\mathrm{~d}, J=8.4 \mathrm{~Hz}, 1 \mathrm{H}, \mathrm{Ar}, \mathrm{CH}-10)$; ${ }^{13} \mathrm{C}-\mathrm{NMR}\left(\mathrm{CDCl}_{3}\right): \delta, 24.4\left(\mathrm{CH}_{2}, \mathrm{C}-5\right), 28.1\left(\mathrm{CH}_{2}\right.$, $\mathrm{C}-6), 55.6\left(\mathrm{OCH}_{3}\right), 88.09(\mathrm{C}-3), 113.05,113.22$, $117.53,117.56,126.6,127.9,128.8,128.9$, 129.1, 136.6, 141.6, 153.09, 154.6, 159.2, 161.3 (Ar-C and $\mathrm{CN}$ ); MS: $\mathrm{m} / \mathrm{z}(\%): 327\left(\mathrm{M}^{+}, 23.9\right)$ consistent with the molecular formula $\left(\mathrm{C}_{21} \mathrm{H}_{17} \mathrm{~N}_{3} \mathrm{O}\right)$. Anal. Calcd. For $\mathrm{C}_{21} \mathrm{H}_{17} \mathrm{~N}_{3} \mathrm{O}$ (327.13): C, 77.04; H, 5.23; N, 12.84. Found: C, $77.11 ; \mathrm{H}, 5.44 ; \mathrm{N}, 12.78 \%$.

\section{2-Amino-5,6-dihydro-8-methoxy-4-phenyl-4H- benzo[h]chromene-3-carbonitrile (3)}

Yield $85 \%$; m.p.: $226-228{ }^{\circ} \mathrm{C}$; IR $\left(U_{\max } / \mathrm{cm}^{-1}\right)$ : 3471, $3392\left(\mathrm{NH}_{2}\right), 2196(\mathrm{CN}), 1695(\mathrm{C}=\mathrm{N}) ;{ }^{1} \mathrm{H}-$ NMR (DMSO- $\left.d_{6}\right): \delta: 1.79(\mathrm{~m}, 1 \mathrm{H}, \mathrm{CH}-5), 2.09(\mathrm{~m}$, $1 \mathrm{H}, \mathrm{CH}-5), 2.55(\mathrm{~m}, 1 \mathrm{H}, \mathrm{CH}-6), 2.69(\mathrm{~m}, 1 \mathrm{H}, \mathrm{CH}-$ 6), $3.72\left(\mathrm{~s}, 3 \mathrm{H}, \mathrm{OCH}_{3}\right), 4.00(\mathrm{~s}, 1 \mathrm{H}, \mathrm{CH}-4), 6.73$ (s, $1 \mathrm{H}, \mathrm{Ar}-\mathrm{CH}-7), 6.77-6.8(\mathrm{~m}, 3 \mathrm{H}, \mathrm{Ar}), 7.2-7.3$ (m, 5H, Ar-H and $\mathrm{NH}_{2}$ ), 7.39 (d, $J=7.8 \mathrm{~Hz}, 1 \mathrm{H}$, Ar-CH-10); ${ }^{13} \mathrm{C}-\mathrm{NMR}$ (DMSO-d $\left.d_{6}\right): \delta, 24.7\left(\mathrm{CH}_{2^{-}}\right.$ 5), $27.5\left(\mathrm{CH}_{2}-6\right), 42.7(\mathrm{CH}-4), 55.5\left(\mathrm{OCH}_{3}\right), 56.8$ (C-3), 109.2, 111.7, 113.9, 121.0, 121.5, 122.4, 127.4, 128.1, 129.0, 137.6, 140.2, 144.4, 159.6, 160.3 (Ar-C and CN); MS: $m / z(\%): 330\left(\mathrm{M}^{+}, 29\right)$ consistent with the molecular formula $\left(\mathrm{C}_{21} \mathrm{H}_{18} \mathrm{~N}_{2} \mathrm{O}_{2}\right)$. Anal. Calcd. For $\mathrm{C}_{21} \mathrm{H}_{18} \mathrm{~N}_{2} \mathrm{O}_{2}$ (330.13): C, 76.34; $\mathrm{H}, 5.49$; N, 8.48. Found: C, 76.19; $\mathrm{H}, 5.61 ; \mathrm{N}, 8.32 \%$.<smiles>COc1ccc2c(c1)CCC1=C2OC(N)=C(C#N)C1c1ccccc1C(C)C(C)C(C)C</smiles>

Scheme 1: Synthesis of benzo[h]quinoline (2) and benzo[h]chromene (3) 


\section{X-ray}

For the title compounds, $\mathrm{C}_{21} \mathrm{H}_{17} \mathrm{~N}_{3} \mathrm{O}$ and $\mathrm{C}_{21} \mathrm{H}_{18} \mathrm{~N}_{2} \mathrm{O}_{2}$, the crystallographic data and refinement information are summarized in Table 1. The asymmetric unit of compound 2 contains two independent molecules but in case of compound $\mathbf{3}$ it contains only one molecule as shown in Figure 1. All the bond lengths and angles are in normal ranges [22]. In the crystal packing, Figure 2, molecules of compound $\mathbf{2}$ are linked via six intermolecular hydrogen bonds (Table 2). Molecules of compound $\mathbf{3}$ are linked via two intermolecular hydrogen bonds (Table 2 ).
Compound 2

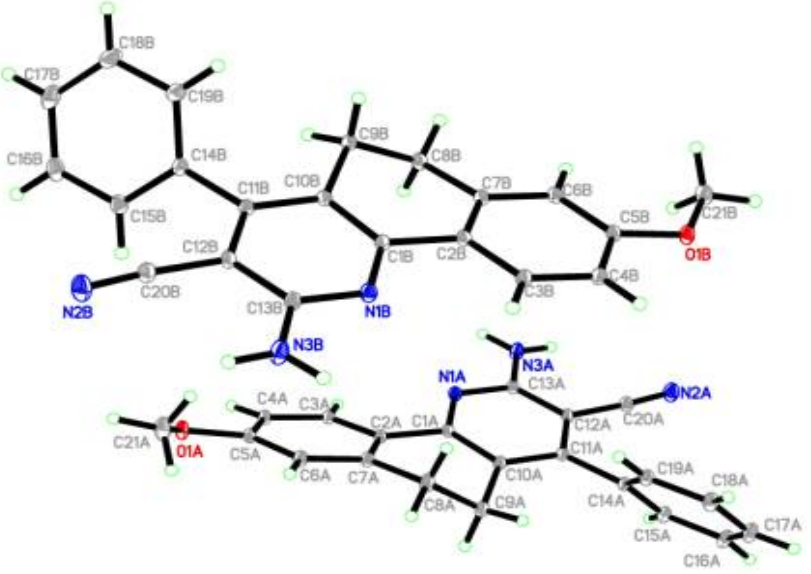

\section{Cytotoxicity}

U373 human glioblastoma cell line was used for in-vitro cytotoxic screening of compounds 2 and 3 , to evaluate their cytotoxicity at 5 different concentrations. Results declared that, compound 2 showed no significant cytotoxic effect on the U373 cells (Figure 3). On the contrary, compound $\mathbf{3}$ showed significant cytotoxic effects on U373 cells starting at very low concentrations $(0.1 \mu \mathrm{g} / \mathrm{mL})$. Moreover, the highest concentration used in this study (200 $\mu \mathrm{g} / \mathrm{mL})$ led to a highly significant effect, decreasing cell viability to $20 \%$ and causing approximately $80 \%$ cell death (Figure 4).

\section{Compound 3}

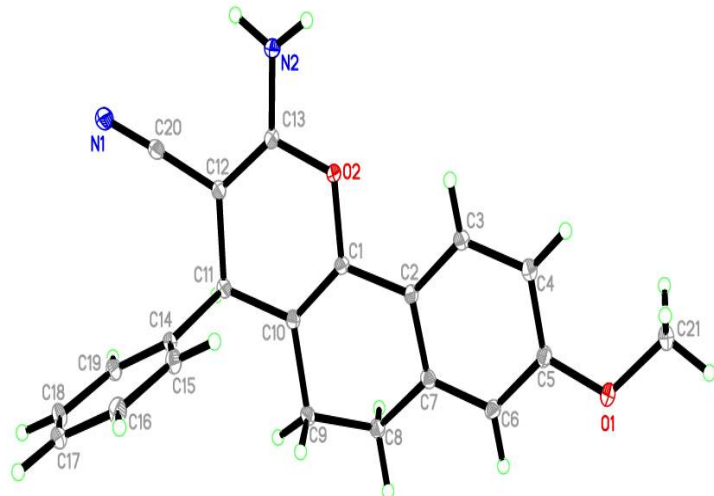

Figure 1: ORTEP diagrams of the titled compounds. Displacement ellipsoids are plotted at $40 \%$ probability level for non-H atoms
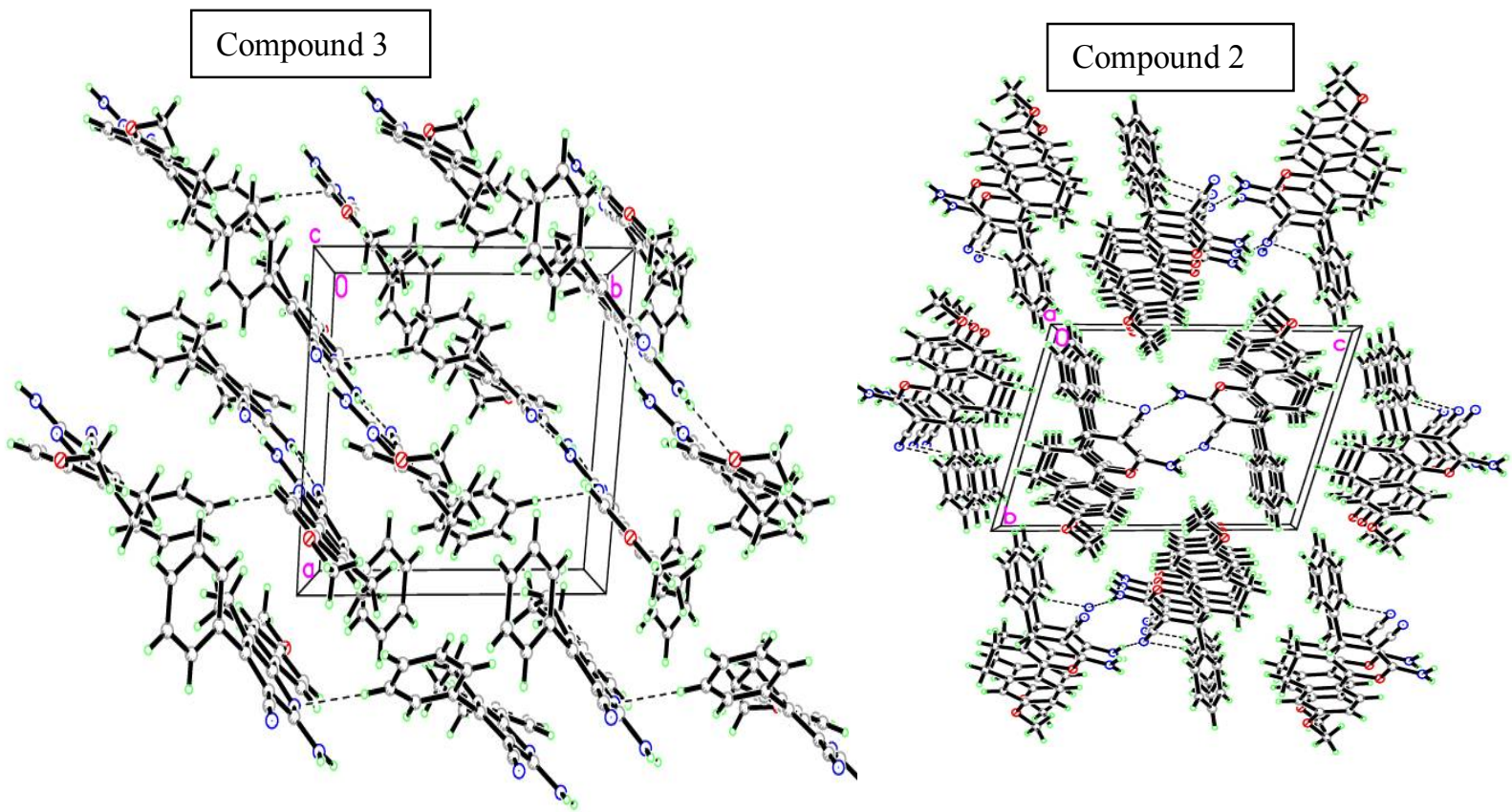

Figure 2: Molecular packing of titled compounds viewed approximately three dimensional networks hydrogen bonds are drawn as dashed lines 
Table 1: X-ray experimental data for compounds 2 and 3

\begin{tabular}{|c|c|c|}
\hline $\begin{array}{l}\text { Crystal data } \\
\text { Chemical formula }\end{array}$ & $\begin{array}{l}\text { Compound } 2 \\
\mathrm{C}_{21} \mathrm{H}_{17} \mathrm{~N}_{3} \mathrm{O}\end{array}$ & $\begin{array}{c}\text { Compound 3 } \\
\mathrm{C}_{21} \mathrm{H}_{18} \mathrm{~N}_{2} \mathrm{O}_{2}\end{array}$ \\
\hline Molecular weight & 327.38 & 330.37 \\
\hline Crystal system, space group & Triclinic, $P-1$ & Triclinic, $P-1$ \\
\hline Temperature $(\mathrm{K})$ & 100 & 100 \\
\hline$a, b, c(\AA)$ & $10.3257(4), 11.3877(4), 14.5723(5)$ & $5.8471(2), 10.7343(4), 13.7601(6)$ \\
\hline$\alpha, \beta, y\left(^{\circ}\right)$ & $94.304(1), 108.719(1), 93.150$ (1) & $103.191(1), 97.519(1), 102.448$ (1) \\
\hline $\mathrm{V}\left(\AA^{3}\right)$ & $1612.61(10)$ & $806.23(5)$ \\
\hline Z & 4 & 2 \\
\hline Radiation type & Mo Ka & Mo Ka \\
\hline$\mu\left(\mathrm{mm}^{-1}\right)$ & 0.09 & 0.09 \\
\hline Crystal size (mm) & $0.60 \times 0.52 \times 0.14$ & $0.57 \times 0.21 \times 0.16$ \\
\hline \multicolumn{3}{|l|}{ Data collection } \\
\hline Diffractometer & Bruker APEX-II D8 Venture & Bruker APEX-II D8 Venture \\
\hline Absorption correction & $\begin{array}{c}\text { Multi-scan } \\
\text { SADABS Bruker } 2014\end{array}$ & $\begin{array}{c}\text { Multi-scan } \\
\text { SADABS Bruker } 2014\end{array}$ \\
\hline Tmin, Tmax & $0.951,0.988$ & $0.951,0.988$ \\
\hline $\begin{array}{l}\text { No. of measured, independent and } \\
\text { observed }[I>2 \sigma(I)] \text { reflections }\end{array}$ & $82401,12334,10356$ & $45149,6163,4595$ \\
\hline $\mathrm{R}_{\text {int }}$ & 0.048 & 0.056 \\
\hline \multicolumn{3}{|l|}{ Refinement } \\
\hline $\mathrm{R}\left[F^{2}>2 \sigma\left(F^{2}\right)\right], \mathrm{wR}\left(F^{2}\right), \mathrm{S}$ & $0.045,0.126,1.05$ & $0.048,0.126,1.05$ \\
\hline No. of reflections & 12334 & 6163 \\
\hline No. of parameters & 469 & 235 \\
\hline No. of restraints & 0 & 0 \\
\hline$\Delta \rho_{\max }, \Delta \rho_{\min }\left(\mathrm{e} \AA^{-3}\right)$ & $0.53,-0.25$ & $0.41,-0.28$ \\
\hline
\end{tabular}

Table 2: Hydrogen-bond geometry $\left(\AA{ }^{\circ}\right)$ for compounds 2 and 3

\begin{tabular}{|c|c|c|c|c|c|}
\hline \multicolumn{6}{|l|}{ Compound 2} \\
\hline$D-H \cdots A$ & $\mathrm{D}-\mathrm{H}$ & $H \cdots A$ & D $\cdots$ & & $\mathrm{D}-\mathrm{H} \cdots \mathrm{A}$ \\
\hline N3A-H1A $\cdots$ N2B & $0.878 \quad(17)$ & $2.261 \quad(17)$ & 3.0169 & (12) & 144.2 (16) \\
\hline N3B-H1B $\cdots N 2 A^{\prime \prime}$ & 0.878 & 2.273 & 3.0232 & (12) & 143.5 \\
\hline $\mathrm{N} 3 \mathrm{~A}-\mathrm{H} 2 \mathrm{~A} \cdots \mathrm{O} 1 \mathrm{~B}^{\prime \prime \prime}$ & 0.889 & 2.426 & 3.2212 & $(12)$ & 149.1 \\
\hline $\mathrm{N} 3 \mathrm{~B}-\mathrm{H} 2 \mathrm{~B} \cdots \mathrm{O} 1 \mathrm{~A}^{\mathrm{IV}}$ & $0.874 \quad(17)$ & $2.293 \quad(17)$ & 3.1212 & (12) & 158.3 \\
\hline $\mathrm{C} 15 \mathrm{~B}-\mathrm{H} 15 \mathrm{~B} \cdots \mathrm{O} 1 \mathrm{~A}^{\mathrm{v}}$ & 0.9300 & 2.5900 & 3.2959 & (12) & 133.00 \\
\hline $\mathrm{C} 18 \mathrm{~A}-\mathrm{H} 18 \mathrm{~A} \cdots \mathrm{N} 1 \mathrm{~B}^{\mathrm{V}}$ & 0.9300 & 2.5900 & 3.4680 & $(12)$ & 157.00 \\
\hline
\end{tabular}

Symmetry codes: (i) $\mathrm{x}, \mathrm{y}-1, \mathrm{z}-1$; (ii) $\mathrm{x}, \mathrm{y}+1, \mathrm{z}+1$; (iii) $\mathrm{x}, \mathrm{y}-1, \mathrm{z}$; (iv) $\mathrm{x}, \mathrm{y}+1, \mathrm{z}$; (v) - $\mathrm{x}+1,-\mathrm{y}+1,-\mathrm{z}+1$; (vi) $-\mathrm{x}+1,-\mathrm{y}+2$, -z.

\begin{tabular}{|c|c|c|c|c|}
\hline \multicolumn{5}{|l|}{ Compound 3} \\
\hline $\mathrm{D}-\mathrm{H} \cdots A$ & $\mathrm{D}-\mathrm{H}$ & $H \cdots A$ & $D \cdots A$ & $\mathrm{D}-\mathrm{H} \cdots \mathrm{A}$ \\
\hline $\mathrm{N} 2-\mathrm{H} 2 \mathrm{~N} 2 \cdots \mathrm{N} 1^{\prime}$ & $0.895 \quad(18)$ & $2.141 \quad(18)$ & $3.0235 \quad(16)$ & $168.6 \quad(16)$ \\
\hline $\mathrm{C} 15-\mathrm{H} 15 \mathrm{~A} \cdots \mathrm{N} 1 "$ & 0.9500 & 2.5500 & 3.4266 & 154.00 \\
\hline
\end{tabular}

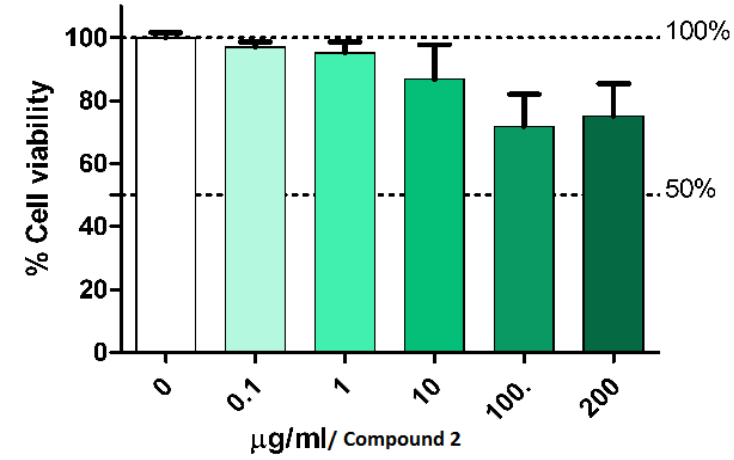

Figure 3: Effect of compound 2 on U373 cell survival. U373 cells were incubated for $48 \mathrm{~h}$ with $0.1,1,10,100$ or $200 \mu \mathrm{g} / \mathrm{mL}$ for compound 2. Cell viability was determined by WST-1 assay. Data expressed as mean \pm S.E.M $(n=3$ or 4$)$

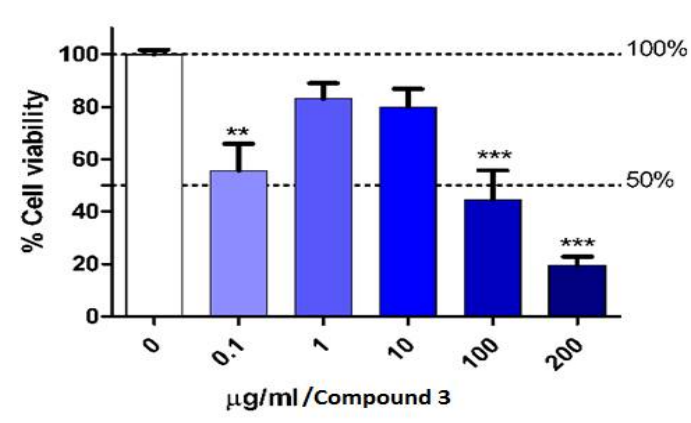

Figure 4: Effect of compound 3 on U373 cell survival. U373 cells were incubated for $48 \mathrm{~h}$ with $0.1,1,10,100$ or $200 \mu \mathrm{g} / \mathrm{mL}$ of compound 3. Cell viability was determined by WST-1 assay. Data expressed as mean $\pm \operatorname{SEM}(\mathrm{n}=3$ or 4$) ;{ }^{* *} p<0.01,{ }^{* * *} p<0.001$ vs. control untreated cells, one-way ANOVA 


\section{DISCUSSION}

The structures of benzo[h] quinoline-3carbonitrile 2 and benzo[h]chromene-3carbonitrile 3 have been established by $\mathrm{x}$-ray crystallography and supported by spectral data. Mass spectra revealed a $[\mathrm{M}]^{+}$ion peaks at 327 and 330 assignable to the molecular weight of compounds 2 and $\mathbf{3}$, respectively. In ${ }^{1} \mathrm{H}$ NMR spectra characteristic signals resonating at $\delta=$ $5.1 \mathrm{ppm}$ (for compound 2) and $\delta=7.2-7.3 \mathrm{ppm}$ (for compound 3) were typical for $\mathrm{NH}_{2}$ groups. IR showed absorption bands at 3475-3471, 3379$3392\left(\mathrm{NH}_{2}\right), 2208,2196(\mathrm{CN}) \mathrm{cm}^{-1}$.

The anticancer activity results declared that compound 2 showed no significant cytotoxic effect on the U373 cells. Higher concentrations starting at $100 \mu \mathrm{g} / \mathrm{mL}$ demonstrated a slight nonsignificant decrease in cell viability compared to the controls (untreated cells). Incubating the U373 cells with $100 \mu \mathrm{g} / \mathrm{mL}$ of compound 2 for 48 h decreased cell viability to approximately $72 \%$ compared to the control (Figure 3), however, this effect was not statistically significant. On the other hand, compound $\mathbf{3}$ demonstrated high cytotoxic effects towards U373 human glioblastoma cell line. Incubation of U373 cells with $0.1 \mu \mathrm{g} / \mathrm{mL}$ of compound 3 decreased cell viability significantly to approximately $55 \%$, surprisingly increasing concentrations ranging from $1-10 \mu \mathrm{g} / \mathrm{mL}$ had a mild non-significant effect on cell viability (approximately $80 \%$ ). A remarkable cytotoxic effect was seen again at $100 \mu \mathrm{g} / \mathrm{mL}$ decreasing viability significantly to 45 $\%$, and $200 \mu \mathrm{g} / \mathrm{mL}$ of compound 3 decreased cell viability by up to $20 \%$, meaning it led to approximately $80 \%$ cell death (Figure 4 ).

\section{CONCLUSION}

The present study provides a simple and rapid method for synthesizing benzo[h]quinoline 2 and benzo[h]chromene 3 . The chromene moiety of compound 3 may be responsible for the high cytotoxicity, thus underlining the importance of the development of chromene derivatives in future work, with the aim to synthesize more active and less toxic products.

\section{DECLARATIONS}

\section{Acknowledgement}

This research project was supported by a grant from Research Center of the Female Scientific and Medical Colleges, Deanship of Scientific Research, King Saud University. Human glioblastoma cells U373 were kindly provided by Dr König, Heidelberg, Germany.

\section{Conflict of Interest}

No conflict of interest associated with this work.

\section{Contribution of Authors}

The authors declare that this work was done by the authors named in this article and all liabilities pertaining to claims relating to the content of this article will be borne by them.

\section{Open Access}

This is an Open Access article distributed under the terms of the Creative Commons Attribution License, which permits unrestricted use, distribution, and reproduction in any medium, provided the original work is properly credited.

\section{REFERENCES}

1. Pawar SP, Kondhare DD, Zubaidha PK. Synthesis and evaluation of antioxidant activity of 2-styrylchromones. Med Chem Res 2013; 22: 753-757.

2. Li H, Wang $X, X u$, Zeng L, Cheng $K$, Gao P, Sun $Q$, Liao W, Zhang J. Synthesis and biological evaluation of a novel class of coumarin derivatives, Bioorg Med Chem Lett 2014; 24: 5274-5278.

3. Patel RV, Kumari P, Rajani DP, Chikhalia KH. Synthesis of coumarin-based 1,3,4-oxadiazol-2-ylthio- $N$ phenyl/benzothiazolyl acetamides as antimicrobial and anti- tuberculosis agents. Med Chem Res 2013; 22: 195-210.

4. El-Haggar R, Al-Wabli RI. Anti-Inflammatory Screening and Molecular Modeling of Some Novel Coumarin Derivatives. Molecul 2015; 20: 5374-5391.

5. Witaicenis $A$, Seito $L N$, Chagas AS, Junior LDA, Luchini AC, Rodrigues-Orsi $P$, Cestari SH, Di Stasi LC. Antioxidant and intestinal anti-inflammatory effects of plant-derived coumarin derivatives. Phytomed 2014; 21 : 240-246.

6. Thota S, Nadipelly K, Shenkesi A, Yerra R. Design, synthesis, characterization, antioxidant and in vitro cytotoxic activities of novel coumarin thiazole derivatives, Med Chem Res 2015; 24: 1162-1170.

7. Erosa-Rejon GJ, Yam-Puc A, Chan-Bacab MJ, GimenezTurbax A, Salamanca E, Pena-Rodriguez LM, Sterner O. Benzochromenes from the roots of Bourreria Pulchra. Photochem Lett 2010; 3: 9-12.

8. Carrigan CN, Patel SA, Cox HD, Bolstad ES, Gerdes JM, Smith WE, Bridges RJ, Thompson CM. The development of benzo- and naphtho-fused quinoline-2, 4-dicarboxylic acids as vesicular glutamate transporter (VGLUT) inhibitors reveals a possible role for

Trop J Pharm Res, November 2016; 15(11): 2342 
neuroactive steroids. Bioorg Med Chem. Lett 2014; 24 850-854.

9. Dolan N, Gavin DP, Eshwika A, Kavanagh K, McGinley J, Stephens JC. Synthesis, antibacterial and anti-MRSA activity, in vivo toxicity, and a structure-activity relationship study of a quinoline thiourea. Bioorg Med Chem Lett 2016; 26: 630-635.

10. Sun X-Y, Wua R, Wen X, Guo L, Zhou C-P, Li J, Quan Z$S$, Bao J. Synthesis and evaluation of antibacterial activity of 7-alkyloxy-4,5-dihydro-imidazo[1,2-a]quinoline derivatives. Eur J Med Chem 2013; 60: 451-455.

11. Sangani CB, Makawana JA, Zhang $X$, Teraiya SB, Lin L, Zhu H-L. Design, synthesis and molecular modeling of pyrazole-quinoline-pyridine hybrids as a new class of antimicrobial and anticancer agents. Eur J Med Chem 2014; 76: 549-557.

12. Lu W-J, Wicht KJ, Wang L, Imai K, Mei Z-W, Kaiser M, El Sayed IE, Egan TJ, Inokuchi T. Synthesis and antimalarial testing of neocryptolepine analogues: Addition of ester function in SAR study of 2,11disubstituted indolo[2,3-b]quinolines. Eur J Med Chem 2013; 64: 498-511.

13. Mishra A, Batchu $H$, Srivastava K, Singh P, Shukla PK, Batra $S$. Synthesis and evaluation of new diaryl ether and quinoline hybrids as potential antiplasmodial and antimicrobial agents Bioorg Med Chem Lett 2014; 24 1719-1723.

14. Bedoya LM, Abad MJ, Calongea E, Saavedra LA, Gutierrez MC, Kouznetsov VV, Alcami J, Bermejo P. Quinoline-based compounds as modulators of HIV transcription through NF-KB and Sp1 inhibition. Antiviral Res 2010; 87: 338-344.
15. Srihari $P$, Padmabhavani $B$, Ramesh $S$, Kumar $Y B$, Singh A, Ummanni R. PMA-SiO2 catalyzed synthesis of indolo[2,3-c]quinolines as potent anticancer agents. Bioorg Med Chem Lett 2015; 25: 2360-2365.

16. Spano V, Parrino B, Carbone A, Montalbano A, Salvador $A$, Brun $P$, Vedaldi D, Diana $P$, Cirrincione $G$, Barraja $P$. Pyrazolo[3,4-h]quinolines promising photosensitizing agents in the treatment of cancer. Eur $\mathrm{J}$ Med Chem 2015; 102: 334-351.

17. Haiba ME, Al-Abdullah ES, Edrees MM, Khalifa NM. Synthesis and Characterization of Some Substituted 3, 4-dihydronaphthalene Derivatives through Different Enaminones as potent cytotoxic agents. Drug Res 2015; 65: 9-17.

18. Haiba ME, Al-Abdullah ES, Hilmy NM. Synthesis and Cytotoxicity of Some New Substituted Hydronaphthalene Derivatives, Am Chem Sci J 2013; 3: 203-220.

19. Al Mutairi MS, Al-Abdullah ES, Haiba ME, Khedr MA, Zaghary WA. Synthesis, Molecular Docking and Preliminary in-Vitro Cytotoxic Evaluation of some Substituted Tetrhydronaphthalene(2',3',4',6'-Tetra-OAcetyl- $\beta-D-$ Gluco/Galactopyranosyl) Derivatives. Molecul 2012; 17: 4717- 4732.

20. Sheldrick GM. A short history of SHELX. Acta Crystallog 2008; 64A: 112-122.

21. Sheldrick GM. SHELXTL-PC (Version 5.1), Siemens Analytical Instruments, Inc., Madison, WI, 1997.

22. Allen FH, Kennard O, Watson DG, Brammer L, Orpen $A G$, Taylor $R$. Tables of bond lengths determined by $X-$ ray and neutron diffraction. Part 1. Bond lengths in organic compounds, J Chem Soc Perkins Trans II 1987; 1-19. 